\title{
Stable isotopes indicate sex-specific and long-term individual foraging specialisation in diving seabirds
}

\author{
Stuart Bearhop ${ }^{1, *}$, Richard A. Phillips ${ }^{2}$, Rona McGill ${ }^{3}$, Yves Cherel ${ }^{4}$, \\ Deborah A. Dawson ${ }^{5}$, John P. Croxall ${ }^{2}$ \\ ${ }^{1}$ Quercus, School of Biology \& Biochemsistry, MBC, Queen's University of Belfast, Lisburn Road, Belfast BT9 7BL, UK \\ ${ }^{2}$ British Antarctic Survey, Natural Environment Research Council, High Cross, Madingley Road, \\ Cambridge CB3 0ET, UK \\ ${ }^{3}$ Scottish Universities Environmental Research Centre, Scottish Enterprise Technology Park, East Kilbride G75 0QF, UK \\ ${ }^{4}$ CEBC-CNRS, BP 14, 79360 Villiers-en-Bois, France \\ ${ }^{5}$ Sheffield Molecular Genetics Facility, Department of Animal \& Plant Sciences, University of Sheffield, Western Bank, \\ Sheffield S10 2TN, UK
}

\begin{abstract}
An important aspect of foraging ecology is the extent to which different individuals or genders within a population exploit food resources in a different manner. For diving seabirds, much of this information relates either to short-term dietary data or indirect measures such as time budgets. Moreover, dietary specialisation can be difficult to detect due to biases associated with conventional sampling techniques. We used stable isotope ratios in blood and feathers to infer trophic and habitat specialisations among 4 diving seabird taxa - the gentoo penguin Pygoscelis papua, the macaroni penguin Eudyptes chrysolophus, the South Georgian shag Phalacrocorax (atriceps) georgianus and the Kerguelen shag $P$. (atriceps) verrucosus. This allowed us to investigate foraging specialisation and assess whether social dominance or differences in foraging preferences explained the observed patterns. In all taxa where sexes were known we found that males foraged at a higher trophic level $\left(\delta^{15} \mathrm{~N}\right.$ values) than females, although this was not significant in macaroni penguins. We believe that this is linked to a dual foraging strategy among female macaroni penguins. For South Georgian shags, we found that sex-related dietary differences persisted for long periods (inferred from stable isotope analyses of feathers and blood). We suggest that the trophic differences are driven by differences in physiological performance, with males tending to dive deeper than females because of their larger size, and hence able to access higher trophic level prey items. Moreover, male and female shags tend to forage at different times of day; therefore, social dominance by males is unlikely to be driving the observed differences. We also recorded highly significant relationships between stable isotope signatures in blood (representing the breeding season diet) and those in feathers (mostly representing the previous non-breeding season diet) in both the South Georgian and Kerguelen shags. This strongly suggests that these 2 taxa include individuals with distinct foraging specialisation (and most probably foraging locations) that are maintained over long periods.
\end{abstract}

KEY WORDS: Penguin $\cdot$ Shag $\cdot$ Trophic level $\cdot \delta^{13} \mathrm{C} \cdot \delta^{15} \mathrm{~N}$

Resale or republication not permitted without written consent of the publisher

\section{INTRODUCTION}

The extent to which different individuals in a population vary in the manner in which they exploit food resources is an important feature of foraging ecology.
This is often manifested as a gender-related difference in spatial distribution, with segregation of male and female foraging habitats a fairly common phenomenon, particularly in migratory birds (Cristol et al. 1999, Catry et al. in press). Sexual segregation in foraging 
areas has been observed over variable spatial scales, from the localised habitat segregation seen in some Nearctic passerine species (Marra \& Holmes 2001) to large-scale regional differences in distribution associated with differential migration (Cristol et al. 1999). The degree of segregation may change temporally, as constraints associated with different components of the annual cycle take effect (Phillips et al. 2004). Sexual segregation can also occur within habitats, whereby males and females have similar foraging areas but specialise on different types of prey (Newton 1998). Individual feeding specialisations that are not gender-specific are less frequently reported and much more poorly understood, but there is some evidence of these among waders (e.g. Durell 2000), gulls (Spear 1993) and skuas (Bearhop et al. 2000, Votier et al. 2004). In these cases, many individuals within the population show foraging specialisation either as a consequence of social status and (or) variation in foraging abilities.

There are two not necessarily mutually exclusive proximate hypotheses that have been proposed to explain why all individuals may not behave in the same manner when it comes to exploiting food resources. The first is that dominant individuals (usually males) exclude subordinates (often females and immatures) from high quality habitats (Gauthreaux 1978, Greenberg 1986), which does appear to explain segregation patterns in some passerines (Marra \& Holmes 2001). The second is that differences in foraging habitat selection or utilisation among individuals, or between sexes, reflects either variability in physiology/anatomy, specialisation of breeding roles or even the chance learning of a skill (e.g. Selander 1966, Durell 2000, Catry et al. in press).

Among diving seabirds, foraging habitat differences between sexes or individuals might be predicted since they tend to be highly colonial and have limited foraging ranges, and thus the potential for intra specific competition is very high. Several studies suggest that sex-related foraging specialisation may be fairly widespread, particularly amongst penguins and shags Phalacrocorax spp. (e.g. Volkman et al. 1980, Clarke et al. 1998, Kato et al. 2000, Casaux et al. 2001, Ishikawa \& Watanuki 2002). Moreover, the lack of overlap in feeding ranges of South Georgian shags $P$. (atriceps) georgianus from adjacent colonies, as well as the considerable variability in time budgets amongst individuals within the same colony (Wanless et al. 1992, Wanless \& Harris 1993) is strongly suggestive of a degree of individual foraging specialisation. However, the extent to which indirect evidence from time budgets reflects dietary specialisation is unclear. Nor is such specialisation easy to detect using conventional dietary sampling techniques, which suffer from a number of well-known biases and usually represent diet over relatively short time periods during the breeding season (Votier et al. 2001). This is important since competition pressure should be relaxed during the non-breeding season when seabirds are not constrained to the colony area, although shags do remain coastal during the winter period.

An alternative approach to quantifying and elucidating diet is to measure stable isotope ratios of nitrogen and carbon in different tissues. This has been used recently to demonstrate both age- and sex-based dietary segregation in the southern giant petrel Macronectes giganteus (Forero et al. 2005). The ratio of ${ }^{15} \mathrm{~N}$ to ${ }^{14} \mathrm{~N}$ (expressed as $\delta^{15} \mathrm{~N}$ ) increases in a stepwise manner at each trophic level, such that consumer tissues have values between 3 and 5\% greater than those of the diets from which they were synthesised (DeNiro \& Epstein 1981, Hobson \& Clark 1992, Bearhop et al. 2002). Although the ratio of ${ }^{13} \mathrm{C}$ to ${ }^{12} \mathrm{C}$ (expressed as $\delta^{13} \mathrm{C}$ ) also changes slightly with trophic level (typically by around $1 \%$ ), the major source of variation in $\delta^{13} \mathrm{C}$ occurs over small and large spatial scales as a consequence of variation in the rates of primary production, reflecting differences in photosynthetic biochemistry within and between primary producer communities (Rau et al. 1992, Lathja \& Marshall 1994). As the $\delta^{13} \mathrm{C}$ values in primary producers are reflected throughout the foodwebs they fuel, these spatial patterns can allow inferences to be made about the locations in which animals forage, and enable discrimination between (amongst other things) inshore versus offshore, or benthic versus pelagic feeding habits (Hobson et al. 1994).

A further advantage of stable isotope analysis is that tissue isotope signatures generally reflect diet throughout the period of tissue synthesis (Hobson \& Clark 1992, Bearhop et al. 2002). Hence, by selecting particular tissues, information spanning several temporal scales can be collected during a single sampling event. In the case of birds, whole blood integrates dietary information over 3 to 4 wk prior to sampling (Hobson \& Clark 1992, Haramis et al. 2001, Bearhop et al. 2002, Pearson et al. 2003). Similarly, bird feathers reflect the diet during the period of feather synthesis, and because they are metabolically inert this information is preserved more or less indefinitely (Mitzutani et al. 1991, Hobson \& Clark 1992, Bearhop et al. 2002). If a moult occurs during the non-breeding season, information on winter feeding ecology can be accessed easily (Bearhop et al. 2000, Cherel et al. 2000, 2005), something that would be difficult if not impossible to achieve using conventional techniques. In addition, collection of a random sample of body feathers will probably reflect dietary preferences across the entire moult cycle (several months). Consequently, correlations in stable isotope ratios in different tissues from 
the same individuals could potentially reveal persistent long-term foraging preferences.

In this study, we used stable isotope techniques to assess the degree of sexual segregation and individual foraging specialisation in a guild of 3 diving birds from South Georgia (the gentoo penguin Pygoscelis papua, the macaroni penguin Eudyptes chrysolophus and the South Georgian shag Phalacrocorax [atriceps] georgianus) and 1 species from Kerguelen (the Kerguelen shag $P$. [atriceps] verrucosus). The taxonomic status of the 2 shag taxa is of some debate, although their foraging behaviours are different and are thus, at the very least, ecologically distinct. We have also attempted to determine whether social dominance or different foraging preferences might explain the observed patterns. Moreover using the stable isotope approach allowed us to undertake the first assessment of longterm dietary specialisations in some of these populations.

\section{MATERIALS AND METHODS}

During January and February 2002, we sampled blood from South Georgian shags, gentoo and macaroni penguins during mid to late chick rearing at Bird Island, South Georgia $\left(54^{\circ} 00^{\prime} \mathrm{S}, 38^{\circ} 03^{\prime} \mathrm{W}\right)$. Following collection, samples were returned within 1 to $3 \mathrm{~h}$ to the laboratory, and blood cells were isolated by centrifugation of the sample and removal of the supernatant (plasma). In February 2000, we also sampled whole blood from 11 Kerguelen shags rearing chicks at Mayes Island $\left(49^{\circ} 28^{\prime} \mathrm{S}, 69^{\circ} 57^{\prime} \mathrm{E}\right)$, located within the sheltered Baie du Morbihan, Kerguelen Archipelago

We also collected a random sample of 8 to 10 body feathers from South Georgian shags and the tip of 2 primaries from 11 Kerguelen shags. Kerguelen shags were not moulting their primaries (apart from a single individual) and the sampled feathers were not fresh and fully-grown. The chronology of body feather moult in the shags is not well known, but it seems likely that these feathers are replaced over an extended period, beginning in some cases in the summer, but with most re-growth concentrated in the autumn after adults have finished breeding (Rasmussen 1988). Moreover, only 1 of a total of 51 South Georgian shags examined in $2 \mathrm{yr}$ during chick-rearing was actively moulting a small number of body feathers. Thus, the stable isotope signatures of whole blood or blood cells will reflect the breeding season, and those of feathers (both body and primaries) will represent a period of dietary intake during moult (in the case of body feathers this will include a substantial proportion of the non-breeding season). Moreover even if some of the primary feathers in our sample were grown during the breeding season, these would reflect the diet between 10 and 12 mon prior to the period reflected by the blood sample. South Georgian shags were sexed from vocalisations (Bernstein \& Maxson 1984) or from DNA extracted from a blood sample (Fridolfsson \& Ellegren 1999), gentoo penguins from extracted DNA (Fridolfsson \& Ellegren 1999), and macaroni penguins from bill dimensions (Williams \& Croxall 1991). Data on the sexes of the Kerguelen shags were not collected.

Whole blood and blood cells were stored frozen until preparation for stable isotope analyses (SIA), whereupon they were freeze-dried and homogenised. Feather samples were dried, stored in sealed plastic bags, and then later ground to a fine powder in a freezer mill operating at liquid nitrogen temperature prior to SIA. Nitrogen and carbon isotope ratios for blood and feathers were measured by continuous-flow isotope ratio mass spectrometry (CF-IRMS) using both a Carlo Erba (Model NA 1500) EA linked to a Finnigan tracer mat and a Costech (Model ECS 4010) EA combined with a Thermo Finnigan delta plus XP. Approximately $0.7 \mathrm{mg}$ of each sample was combusted in a tin cup for the simultaneous determination of nitrogen and carbon isotope ratios. We analysed 2 internal laboratory standards (Sigma-Aldrich gelatin, and LSTD6 [a solution of sucrose and ammonium sulphate]) for every 8 to 10 unknown samples in each analytical sequence, assuring good matching of results and allowing any instrument drift to be corrected. stable isotope ratios were expressed in $\delta$ notation as parts per thousand (\%) deviation from the international standards V-PDB (carbon) and AIR (nitrogen), according to the equation:

$$
\delta X=\left[\left(\mathrm{R}_{\text {sample }} / \mathrm{R}_{\text {standard }}\right)-1\right] \times 1000
$$

where $X$ is ${ }^{15} \mathrm{~N}$ or ${ }^{13} \mathrm{C}$ and $\mathrm{R}$ is the corresponding ratio ${ }^{15} \mathrm{~N}:{ }^{14} \mathrm{~N}$ or ${ }^{13} \mathrm{C}:{ }^{12} \mathrm{C}$. Measurement precision of both $\delta^{15} \mathrm{~N}$ and $\delta^{13} \mathrm{C}$ was estimated to be $\leq 0.2 \%$. All values presented are means $\pm 1 \mathrm{SD}$ unless otherwise stated.

\section{RESULTS}

Stable nitrogen and carbon isotope values for all tissues sampled from the 4 taxa are presented in Fig. 1. For birds of known sex, in all cases $\delta^{15} \mathrm{~N}$ signatures of male tissues were greater than those of females. However, while Student's $t$-tests showed that these differences were significant for gentoo penguins (Table $1 ; t_{13}=3.46$, $\mathrm{p}=0.004$ ) and South Georgian shags (Table 1 ; blood, $t_{14}$ $=3.22, \mathrm{p}=0.006$; feathers, $\left.t_{14}=3.12, \mathrm{p}=0.008\right)$, this was not the case for macaroni penguins (Table $1 ; t_{14}=1.75, \mathrm{p}$ $=0.1$ ). There were no sex-related differences in $\delta^{13} \mathrm{C}$ signatures in any of the tissues or species sampled (Table 1). All these analyses were originally run in general linear models (GLMs) with body mass included as a covariate 


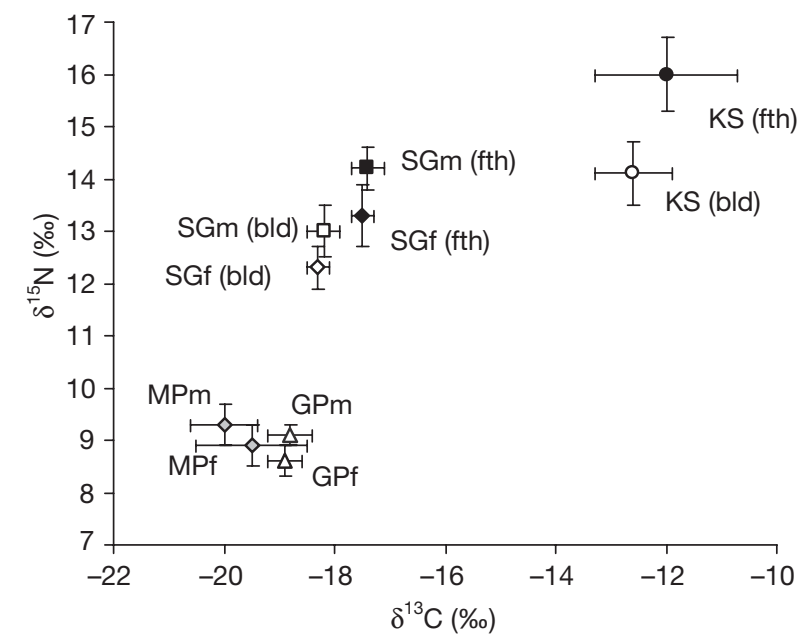

Fig. 1. Pygoscelis papua (gentoo penguin, GP), Eudyptes chrysolophus (macaroni penguin, MP), Phalacrocorax (atriceps) georgianus (South Georgian shag, SG), P. (atriceps) verrucosus (Kerguelen shag, KS). Mean stable carbon and nitrogen isotope signatures $( \pm 1 \mathrm{SD})$ for all tissues and all taxa sampled. Data for penguins and South Georgian shags are divided into males (m) and females (f), for the 2 shag taxa into blood (bl) and feathers (fth). Differences between blood and feather values of this magnitude are likely to be a consequence of differences in diet tissue discrimination factor, rather than of changes in prey preferences over time

and a mass/sex interaction term. Mass was not significant in any of these analyses even when sex was removed from the models. The non-significant difference in macaroni penguins $\left(t_{14}=1.8, \mathrm{p}=0.102\right)$ is not likely to be due to lack of power, but may be related to the predominance of 1 of 2 alternative foraging strategies in individual females. Variance in female macaroni penguin $\delta^{13} \mathrm{C}$ signatures (1.01) was significantly greater $\left(F_{14}=\right.$ $7.02, \mathrm{p}=0.019)$ than in males $(0.36)$. The data for females also showed an obvious bimodal distribution, suggesting 2 different principal foraging locations. Since $\delta^{13} \mathrm{C}$ has a trophic component, we corrected for this by regressing these values upon $\delta^{15} \mathrm{~N}$ signatures in the same tissue $\left(F_{1,14}=4.8, \mathrm{p}=0.048, \mathrm{r}^{2}=0.25\right)$. The Studentised residuals of this relationship were then used in a 1-way ANOVA to compare the values for the 2 groups of

Table 1. Pygoscelis papua, Eudyptes chrysolophus, Phalacrocorax (atriceps) georgianus and $P$. (atriceps) verrucosus. Mean $( \pm 1 \mathrm{SD})$ stable isotope values for males and females of the 3 species of diving seabirds sampled at Bird Island, South Georgia. Gentoo penguins: 6 males, 9 females; macaroni penguins: 8 males, 8 females; South Georgian: shags 8 males, 8 females

\begin{tabular}{|lrrrrr|}
\hline & \multicolumn{2}{c}{$\delta^{15} \mathrm{~N}$} & & \multicolumn{2}{c}{$\delta^{13} \mathrm{C}-$} \\
\cline { 2 - 4 } Species (tissue) & Males & Females & & Males & Females \\
\hline Gentoo penguin (blood cells) & $9.1(0.2)$ & $8.6(0.3)$ & $-18.8(0.4)$ & $-18.9(0.3)$ \\
Macaroni penguin (blood cells) & $9.3(0.4)$ & $8.9(0.4)$ & $-20.0(0.6)$ & $-19.5(1.0)$ \\
South Georgian shag (blood cells) & $13.0(0.5)$ & $12.3(0.4)$ & $-18.2(0.3)$ & $-18.3(0.2)$ \\
South Georgian shag (feathers) & $14.2(0.4)$ & $13.3(0.6)$ & $-17.4(0.3)$ & $-17.5(0.2)$ \\
\hline
\end{tabular}

females with those of males. The results were highly significant $\left(F_{2,13}=20.98, \mathrm{p}<0.001\right)$ with post hoc Scheffé tests $(\mathrm{p}=0.003)$ indicating that values for females in the high $-\delta^{13} \mathrm{C}$ group $(-18.7 \pm 0.2 \%$ ) were significantly different from those of females in the low $-\delta^{13} \mathrm{C}$ group $(-20.0 \pm$ $0.6 \%$ ) and from those of males $(-20.6 \pm 0.3 \%$ ), with no significant difference between the last 2 groups.

In the analyses of individual specialisation we again corrected for the trophic component associated with $\delta^{13} \mathrm{C}$ by regressing these values upon $\delta^{15} \mathrm{~N}$ signatures in the same tissue. In Kerguelen shags, there were significant positive relationships between $\delta^{15} \mathrm{~N}$ and $\delta^{13} \mathrm{C}$ in blood $\left(F_{1,9}=21.4, \mathrm{p}=0.001, \mathrm{r}^{2}=0.68\right)$, and feathers $\left(F_{1,9}=6.6, \mathrm{p}=0.03, \mathrm{r}^{2}=0.43\right)$ (Fig. 2). The same relationships were present, but weaker and of marginal statistical significance in blood and feathers of South Georgian shag $\left(F_{1,14}=4.1, \mathrm{p}=0.063, \mathrm{r}^{2}=0.23\right.$, and $F_{1,14}$ $=3.3, \mathrm{p}=0.09, \mathrm{r}^{2}=0.19$, respectively). The Studentised residuals from these relationships were then compared in order to assess the degree to which individuals maintain their habitat specialisations over longer periods. The relationships were highly significant for birds from both South Georgia (Fig. 3; GLM, $F_{1,14}=6.3, \mathrm{p}=$ $0.025, r^{2}=0.32$, sex and interaction not significant) and Kerguelen (Fig. 3: $F_{1,9}=25.7, p=0.001, r^{2}=0.74$ ). Similar highly significant relationships were also noted for $\delta^{15} \mathrm{~N}$ signatures (Fig. 2; GLM, South Georgian shag, $F_{1,14}=9.67, \mathrm{p}=0.008, \mathrm{r}^{2}=0.41$, sex and interaction not significant; Kerguelen shag, $F_{1,9}=12.4, \mathrm{p}=0.006, \mathrm{r}^{2}=$ $0.58)$, indicating that individuals maintain their trophic positions relative to each other over long periods.

\section{DISCUSSION}

The stable isotope analyses in this study revealed clear differences in the diets of male and female gentoo penguins and South Georgian shags, and a subtler, apparently more complex interaction between sex and foraging area in macaroni penguins. The significantly higher $\delta^{15} \mathrm{~N}$ values in the tissues of male gentoo penguins and South Georgian shags indicate that they feed to a greater extent than females on prey of a higher trophic level. This could reflect a difference in diet composition by species and (or) size class. In a number of fishes and invertebrates (including Antarctic krill Euphausia superba), larger individuals tend to occupy higher trophic levels, and thus have higher $\delta^{15} \mathrm{~N}$ signatures (Lindsay et al. 1998, Schmidt et al. 2003, Pakhomov et al. 2004). Moreover, it has been suggested for several sexually size-dimorphic penguins and 


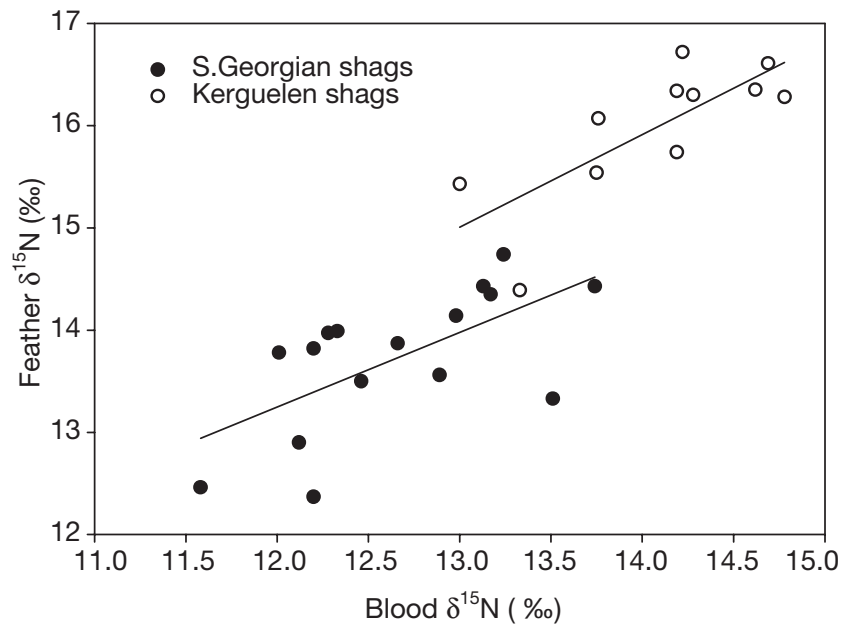

Fig. 2. Phalacrocorax (atriceps) georgianus and P. (atriceps) verrucosus. Significant relationships between blood and feather $\delta^{15} \mathrm{~N}$ signatures in South Georgian (slope $\pm \mathrm{SE}=0.7 \pm$ 0.2 ; intercept $\pm \mathrm{SE}=4.5 \pm 3.0$ ) and Kerguelen (slope $\pm \mathrm{SE}=$ $0.9 \pm 0.3$; intercept $\pm \mathrm{SE}=3.2 \pm 3.6$ ) shags

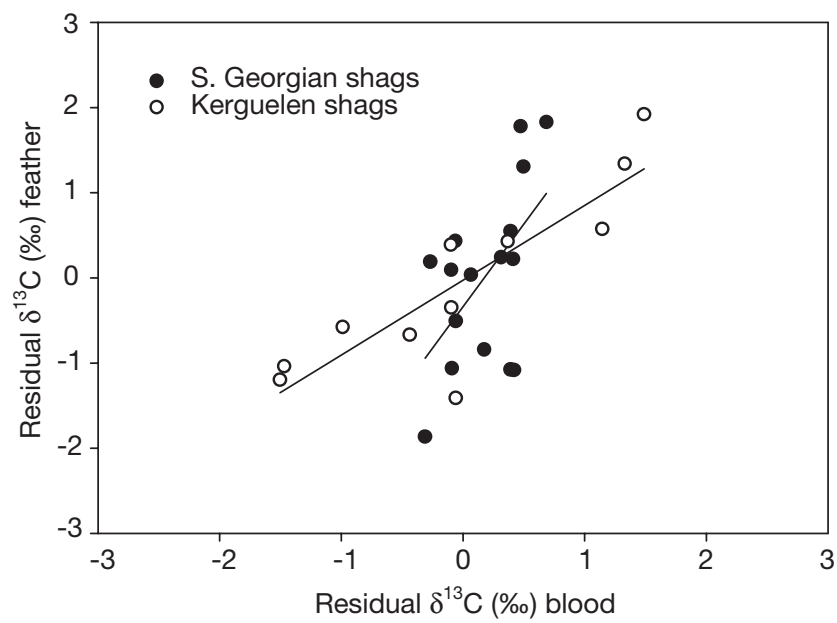

Fig. 3. Phalacrocorax (atriceps) georgianus and P. (atriceps) verrucosus. Residual $\delta^{13} \mathrm{C}$ values in blood significantly related to values in feathers in South Georgian (slope $\pm \mathrm{SE}=1.9 \pm 0.8$; intercept $\pm \mathrm{SE}=-0.3 \pm 2.7$ ) and Kerguelen (slope $\pm \mathrm{SE}=$ $0.9 \pm 0.2$; intercept $\pm \mathrm{SE}=-0.3 \pm 0.2$ ) shags

shags that the larger bills of males allow them to capture larger prey items (Agnew \& Kerry 1995, Kato et al. 2000, Forero et al. 2002).

Other evidence, however, makes a difference in species composition appear more likely. At South Georgia, the bulk of the diet of gentoo penguins during the breeding season consists of Antarctic krill, with the remainder comprising mostly the fishes Champsocephalus gunnari and Lepidonotothen larseni (Williams 1995), which both have higher $\delta^{15} \mathrm{~N}$ values than krill (S. Bearhop et al. unpubl. data). Higher $\delta^{15} \mathrm{~N}$ signatures in the blood of male gentoo penguins are therefore consistent with a breeding-season diet that includes more fishes than that of females. This has been previously reported for a small number of breeding birds diet-sampled in the late 1980s (T. D. Williams unpubl. data cited in Williams 1995), and larger numbers of non-breeders sampled during the winter (Williams 1991). It also appears to be the case for pygoscelid penguins in other colonies (Volkman et al. 1980, Clarke et al. 1998).

Previous studies of macaroni penguins have not revealed a consistent difference between male and female diets, perhaps because of the overall dominance of a single species, Antarctic krill (Williams 1995). In our study, males showed higher $\delta^{15} \mathrm{~N}$ values, but the difference was not significant. However the frequency distribution of $\delta^{13} \mathrm{C}$ indicated 2 discrete groups of females, corresponding to 2 alternative foraging strategies. The $\delta^{13} \mathrm{C}$ values of 1 group were similar to those of gentoo penguins (which feed within 10 to $20 \mathrm{~km}$ of the colony during both summer and winter: Croxall \& Prince 1987, Tanton et al. 2004), suggesting that some female macaroni penguins may have concentrated their recent feeding activity mainly on the nearby shelf. The $\delta^{13} \mathrm{C}$ values of the other group, in contrast, were indicative of foraging much further from the colony. When comparing maximum foraging ranges of adults tracked during chick-rearing, Barlow \& Croxall (2002) recorded an interaction between year and sex, implying no consistent differences between males and females. However, in agreement with isotope results, the overall density-distribution map for females appears to indicate 2 cores, one within the $200 \mathrm{~m}$, and the other around the $2000 \mathrm{~m}$ bathymetric contours, whereas that for males reflects only a core within the $200 \mathrm{~m}$ contour and a generally more dispersed distribution overall. Furthermore, the tracking analysis excluded the shortest foraging trips (those providing $\leq 3$ locations) that could be carried out disproportionately by females.

Even if the identification of these 2 discrete groups is an artefact of the small sample size, the very large range of $\delta^{13} \mathrm{C}$ values exhibited by females $(-18.6$ to $-20.9 \%$ ), compared with males $(-19.4$ to $-20.9 \%$ ), still indicates much greater variability in female foraging strategies. Variable foraging strategies have also been described for male and female Adélie penguins Pygoscelis adeliae, particularly during the broodguard stage (Clarke et al. 1998), although it is unclear whether this was at the individual or a population level. As blood isotope signatures reflect diet over several weeks, it is unlikely that individual female macaroni penguins similarly mix trips of different duration, as observed in albatrosses and petrels (Weimerskirch et al. 1994), but instead it appears that certain birds make consistently shorter, and others longer, foraging trips. 
Sex-related dietary differences have never been previously noted for South Georgian shags (Fig. 1). As with gentoo penguins, the isotope results for the shags could reflect a difference in diet composition by prey species, by size class, or even by prey depth distribution as a consequence of vertical $\delta^{15} \mathrm{~N}$ gradients. However, variation in prey species is the most likely explanation, given that this occurs during the breeding season in a closelyrelated taxon (Kato et al. 1996, Casaux et al. 2001). In any case, the precise explanation is not crucial, as the main points of interest are that substantial between-sex dietary segregation exists and that, according to the consistent differences in isotope values in both blood (indicating breeding season diet) and body feathers (indicating dietary intake over many months), this persists throughout much of, if not the entire, year.

Our data provide support for both the dominance and habitat specialisation hypotheses. For example, in the case of gentoo penguins and South Georgian shags, the sex-related diet differences may be related to dimorphism in size and physiological performance (diving capability). In both these species, males are larger than females, with an average of 5 to $17 \%$ higher biomass, depending on the biometric used (Williams 1995, R. A. Phillips unpubl. data). In general, heavier species dive longer and deeper (Schreer \& Kovacs 1997, Watanuki \& Burger 1999) and this relationship is also known to apply intra specifically among Japanese cormorants Phalacrocorax capillatus (Watanuki et al. 1996). We might therefore expect male gentoo penguins and shags to dive deeper than females. Croxall et al. (1988) found no significant differences in the diving parameters of male and female gentoo penguins, but his results were based on a sample of only 6 birds. Male South Georgian shags tend to make longer dives than females (Wanless et al. 1995), and these dives are almost certainly deeper (Croxall et al. 1991, Kato et al. 2000). In addition, studies on other shags have also recorded males diving deeper on average than females (Watanuki et al. 1996, Kato et al. 2000).

Given the paucity of empirical data from tracked birds, it is difficult to determine whether the dietary difference between male and female gentoo penguins reflects horizontal or vertical spatial segregation, and whether this is related to competitive exclusion or niche differentiation. Segregation by depth seems more likely, as the diet of males includes more fishes (Williams 1991), and foraging trips of gentoo penguins that return with mainly fishes rather than krill include a significantly higher proportion of deep dives (Croxall et al. 1988).

For South Georgian shags, the situation is somewhat clearer. Not only do males and females probably forage routinely at different depths, but they also feed at different times of day, as do all other taxa within the Phalacrocorax atriceps complex (Bernstein \& Maxson
1984, Kato et al. 1992, 2000). Social dominance by males and competitive interaction is therefore unlikely to be an issue and, instead, niche specialisation through differences in morphology and physiological performance (diving capacity) is much more likely to be driving sexual segregation in diet in this species.

Although it seems likely that size is the driving force behind differences in foraging specialisation between the sexes in these species, mass did not explain significant amounts of variation in any of our analyses, even when entered into the models on its own. Thus, there is no simple linear relationship between mass and foraging behaviour, from which we might infer that small males do not appear to forage in the same manner as large females. It is possible, considering our small sample sizes and the amount of overlap in body size between the sexes, that size-based effects would be difficult to detect, but other sex-based traits such as breeding role specialisation may be important.

The range of $\delta^{15} \mathrm{~N}$ values of the blood (11.5 to $13.8 \%$ ) and feathers (12.4 to $14.8 \%$ o) in South Georgian shags indicates substantial dietary breadth during both the breeding and non-breeding seasons, and this is just as pronounced in Kerguelen shags (blood: 13.0 to $14.8 \%$; feathers: 14.4 to $16.7 \%$ o). There were also highly significant correlations in both $\delta^{15} \mathrm{~N}$ and residual $\delta^{13} \mathrm{C}$ values between blood and feathers in birds of both species. As the stable isotope signatures in shag blood represent the breeding period, and those in body feathers represent an extended period, including much of the previous non-breeding season (Rasmussen 1988) (present Fig. 2), this suggests that individuals exhibit foraging specialisation that persists throughout most of the year, and that this phenomenon could be widespread in the species complex. Even though the primary feather tips of Kerguelen shags will reflect a relatively short period, this will still represent the diet sometime between 8 and 14 mo prior to the period reflected by the blood. The correlated $\delta^{15} \mathrm{~N}$ values suggest that each bird maintains a similar relative trophic level over time. Moreover, given that the residuals from the regression of $\delta^{13} \mathrm{C}$ will account for much of the variability associated with trophic level, the significant relationships in Fig. 3 strongly imply that these individuals may forage in the same locations over long periods.

Other circumstantial evidence provides support for a degree of foraging area fidelity. Firstly, adjacent colonies of South Georgian shags maintain mutuallyexclusive foraging areas (Wanless \& Harris 1993). Secondly, there is considerable variability in the time spent foraging by birds within a colony, which has also been inferred to reflect individual specialisation (Wanless et al. 1995). Finally, results from studies of other species including cormorants have shown that individ- 
uals do concentrate their feeding in particular areas (Irons 1998, Grémillet et al. 1999, Hamer et al. 2000, Watanuki et al. 2003). The diet of these shags includes a wide range of benthic and benthic-demersal prey with diverse habitat requirements, and in the case of certain fishes and octopuses a degree of site-fidelity and potentially a limited availability of suitable crevices (Wanless et al. 1992, Ridoux 1994, Casaux \& Ramón 2002). The physical characteristics of the near shore foraging environment utilised by shags is extremely varied in terms of water depth, turbidity and currents (Wanless \& Harris 1993). Experience of local conditions, and the capacity to memorise and repeatedly exploit the same sites could therefore be extremely advantageous, reducing search times and improving diving efficiency. This is particularly true for resident species such as shags, which could maintain high levels of foraging area fidelity throughout the year and potentially their whole life.

The stable isotope analyses in this study have yielded several unique and relatively subtle insights into the foraging ecology of this guild of diving species. Despite small sample sizes, our data provided clear evidence of sexual segregation in gentoo penguins and South Georgian shags, and some indication that this also applied to macaroni penguins (although this requires further investigation). In addition, at least for South Georgian shags, the sex-related foraging preference seemed to be driven by niche specialisation, although we cannot completely exclude the dominance hypothesis. We have also demonstrated that individual seabirds may have distinct foraging preferences with respect to both prey type and foraging area that appear to be maintained over long periods (also see Bearhop et al. 2000). This finding, in particular, has a number of implications for both conservation and our understanding of the processes underlying individual variability in a suite of foraging traits.

Acknowledgements. We are very grateful to J. Tanton for help with fieldwork at Bird Island, and to R. Buckland and D. Ross for carrying out the genetics analyses. We thank 3 anonymous referees for their comments on earlier drafts of this manuscript. The Sheffield Molecular Genetics Facility supported by the Natural Environment Research Council performed the molecular sex-typing (www.shef.ac.uk/misc/ groups/molecol/smgfbirdsexing.html). S.B. was funded by an NERC Postdoctoral Fellowship.

\section{LITERATURE CITED}

Agnew DJ, Kerry R (1995) Sexual dimorphism in penguins. In: Dann P, Norman I, Reilly P (eds) The penguins. Surrey Beatty \& Sons, Sydney, p 299-318

Barlow KE, Croxall JP (2002) Seasonal and interannual variation in foraging range and habitat of macaroni penguins
Eudyptes chrysolophus at South Georgia. Mar Ecol Prog Ser 232:291-304

Bearhop S, Phillips RA, Thompson DR, Waldron S, Furness RW (2000) Variability in mercury concentrations of great skuas Catharacta skua: the influence of colony, diet and trophic status inferred from stable isotope signatures. Mar Ecol Prog Ser 195:261-268

Bearhop S, Waldron S, Votier SC, Furness RW (2002) Factors that influence assimilation rates and fractionation of nitrogen and carbon stable isotopes in avian blood and feathers. Physiol Biochem Zool 75:451-458

Bernstein NP, Maxson SJ (1984) Sexually distinct activity patterns of blue-eyed shags in Antarctica. Condor 86:151-156

Casaux R, Ramón A (2002) The diet of the South Georgia shag Phalacrocorax georgianus at South Orkney Islands in five consecutive years. Polar Biol 25:557-561

Casaux R, Favero M, Silva P, Baroni A (2001) Sex differences in diving depths and diet of Antarctic shags at the South Shetland Islands. J Field Ornithol 72:22-29

Catry P, Phillips RA, Croxall JP (in press) Sexual segregation in birds: patterns, processes and implications for conservation. In: Ruckstuhl KE, Neuhaus P (eds) Sexual segregation. Cambridge University Press, Cambridge, p 351-378

Cherel Y, Hobson KA, Weimerskirch H (2000) Using stable isotope analysis of feathers to distinguish moulting and breeding origins of seabirds. Oecologia 122:155-162

Cherel Y, Hobson KA, Hassani S (2005) Isotopic discrimination between food and blood and feathers of captive penguins: implications for dietary studies in the wild. Physiol Biochem Zool 78:106-115

Clarke J, Manly B, Kerry K, Gardner H, Franchi E, Corsolini S, Focardi S (1998) Sex differences in Adelie penguin foraging strategies. Polar Biol 20:248-258

Cristol DA, Baker MB, Carbone C (1999) Differential migration revisited: latitudinal segregation by age and sex class. Curr Ornithol 15:33-88

Croxall JP, Prince PA (1987) Seabirds as predators on marine resources, especially krill, at South Georgia. In: Croxall JP (ed) Seabirds: feeding ecology and role in marine ecosystems. Cambridge University Press, Cambridge, p 347-368

Croxall JP, Davis RW, O'Connell MJ (1988) Diving patterns in relation to diet of gentoo and macaroni penguins at South Georgia. Condor 90:157-167

Croxall JP, Naito Y, Kato A, Rothery P, Briggs DR (1991) Diving patterns and performance in the Antarctic blue-eyed shag Phalacrocorax atriceps. J Zool 225:177-199

DeNiro MJ, Epstein S (1981) Influence of diet on the distribution of nitrogen isotopes in animals. Geochim Cosmochim Acta 45:341-351

Durell SEALD (2000) Individual feeding specialisation in shorebirds: population consequences and conservation implications. Biol Rev 75:503-518

Forero MG, Tella JL, Hobson KA, Bertellotti M, Blanco G (2002) Conspecific food competition explains variability in colony size: a test in Magellanic penguins. Ecology 83: $3466-3475$

Forero MG, Gonzalez-Solis J, Hobson KA, Donazar JA, Bertellotti M, Blanco G, Bortolotti GR (2005) stable isotopes reveal trophic segregation by sex and age in the southern giant petrel in two different food webs. Mar Ecol Prog Ser 296:107-113

Fridolfsson AK, Ellegren H (1999) A simple and universal method for molecular sexing of non-ratite birds. J Avian Biol 30:116-121

Gauthreax SA Jr (1978) The ecological significance of behavioural dominance. Perspect Ethol 3:17-54 
Greenberg R (1986) Competition in migrant birds in the nonbreeding season. Curr Ornithol 3:251-307

Grémillet D, Wilson RP, Storch S, Gary Y (1999) Three-dimensional space utilization by a marine predator. Mar Ecol Prog Ser 193:263-273

Hamer KC, Phillips RA, Wanless S, Harris MP, Wood AG (2000) Foraging ranges, diets and feeding locations of gannets Morus bassanus in the North Sea: evidence from satellite telemetry. Mar Ecol Prog Ser 200:257-264

Haramis GM, Jorde DG, Macko SA, Walker JL (2001) Stable isotope analysis of canvasback winter diet in Upper Chesapeake Bay. Auk 118:1008-1017

Hobson KA, Clark RG (1992) Assessing avian diets using stable isotopes. 1. Turnover of $\mathrm{C}-13$ in tissues. Condor 94: 181-188

Hobson KA, Piatt JF, Pitocchelli J (1994) Using stable isotopes to determine seabird trophic relationships. J Anim Ecol 63: $786-798$

Irons DB (1998) Foraging area fidelity of individual seabirds in relation to tidal cycles and flock feeding. Ecology 79: 647-655

Ishikawa K, Watanuki Y (2002) Sex and individual difference in foraging behavior of Japanese cormorants in years of different prey availability. J Ethol 20:49-54

Kato A, Croxall JP, Watanuki Y, Naito Y (1992) Diving patterns and performance in male and female blue-eyed cormorants Phalacrocorax atriceps. Mar Ornithol 19:117-129

Kato A, Nishiumi I, Naito Y (1996) Sexual differences in diet of king cormorants at Macquarie Island. Polar Biol 16: $75-77$

Kato A, Watanuki Y, Nishiumi I, Kuroki M, Shaughnessy P, Naito Y (2000) Variation in foraging and parental behavior of king cormorants. Auk 117:718-730

Lathja K, Marshall JD (1994) Sources of variation in the stable isotopic composition of plants. In: Lajtha K, Michener RH (eds) stable isotopes in ecology and environmental science. Blackwell, Oxford, p 1-21

Lindsay DJ, Minagawa M, Mitani I, Kawaguchi K (1998) Trophic shift in the Japanese anchovy Engraulis japonicus in its early life history stages as detected by stable isotope ratios in Sagami Bay, Central Japan. Fish Sci 64: 403-410

Marra PP, Holmes RT (2001) Consequences of dominancemediated habitat segregation in American redstarts during the nonbreeding season. Auk 118:92-104

Mizutani H, Kabaya Y, Wada E (1991) Nitrogen and carbon isotope compositions relate linearly in cormorant tissues and its diet. Isotopenpraxis 27:166-168

Newton I (1998) Population limitation in birds. Academic Press, London

Pakhomov EA, McClelland JW, Bernard K, Kaehler S, Montoya JP (2004) Spatial and temporal shifts in stable isotope values of the bottom-dwelling shrimp Nauticaris marionis at the sub-Antarctic archipelago. Mar Biol 144:317-325

Pearson SF, Levey DJ, Greenberg CH, Martinez del Rio C (2003) Effects of elemental composition on the incorporation of dietary nitrogen and carbon. Oecologia 135: 516-523

Phillips RA, Silk JRD, Phalan B, Catry P, Croxall JP (2004) Seasonal sexual segregation in two Thalassarche albatross species: competitive exclusion, reproductive role specialization or foraging niche divergence? Proc R Soc Lond Ser B 1271:1283-1291

Editorial responsibility: Rory P. Wilson (Contributing Editor), Swansea, UK
Rasmussen PC (1988) Stepwise molt of remiges in blue-eyed and king shags. Condor 90:220-227

Rau GH, Takahashi T, Desmarais DJ, Repeta DJ, Martin JH (1992) The relationship between $\delta^{13} \mathrm{C}$ of organic matter and $\left[\mathrm{CO}_{2}(\mathrm{Aq})\right]$ in ocean surface water data from a JGOFs site in the northeast Atlantic ocean and a model. Geochim Cosmochim Acta 56:1413-1419

Ridoux V (1994) The diets and dietary segregation of seabirds at the subantarctic Crozet Islands. Mar Ornithol 22:1-192

Schmidt K, Atkinson A, Stubing D, McClelland JW, Montoya JP, Voss M (2003) Trophic relationships among Southern Ocean copepods and krill: some uses and limitations of a stable isotope approach. Limnol Oceanogr 48:277-289

Schreer JF, Kovacs KM (1997) Allometry of diving capacity in air-breathing vertebrates. Can J Zool 75:339-358

Selander RK (1966) Sexual dimorphism and differential niche utilization in birds. Condor 68:113-151

Spear LB (1993) Dynamics and effect of western gulls feeding in a colony of guillemots and Brandts cormorants. J Anim Ecol 62:399-414

Tanton JL, Reid K, Croxall JP, Trathan PN (2004) Winter distribution and behaviour of gentoo penguins Pygoscelis papua at South Georgia. Polar Biol 27:299-303

Volkman NJ, Presler P, Trivelpiece W (1980) Diets of pygoscelid penguins at King George Island, Antarctica. Condor 82:373-378

Votier SC, Bearhop S, Ratcliffe N, Furness RW (2001) Pellets as indicators of diet in great skuas Catharacta skua. Bird Study 48:373-376

Votier SC, Bearhop S, Ratcliffe N, Furness RW (2004) Reproductive consequences for great skuas specializing as seabird predators. Condor 106:275-287

Wanless S, Harris MP (1993) Use of mutually exclusive foraging areas by adjacent colonies of blue-eyed shags (Phalacrocorax atriceps) at South Georgia. Colon Waterbirds 16:176-182

Wanless S, Harris MP, Morris JA (1992) Diving behavior and diet of the blue-eyed shag at South Georgia. Polar Biol 12: 713-719

Wanless S, Harris MP, Morris JA (1995) Factors affecting daily activity budgets of South Georgian shags during chick rearing at Bird Island, South Georgia. Condor 97:550-558

Watanuki Y, Burger AE (1999) Body mass and dive duration in alcids and penguins. Can J Zool 77:1838-1842

Watanuki Y, Kato A, Naito Y (1996) Diving performance of male and female Japanese cormorants. Can J Zool 74: 1098-1109

Watanuki Y, Takahashi A, Sato K (2003) Feeding area specialization of chick-rearing Adélie penguins Pygoscelis adeliae in a fast sea-ice area. Ibis 145:558-564

Weimerskirch H, Chastel O, Ackerman L, Chaurand T, Cuenot-Chaillet F, Hindermeyer X, Judas J (1994) Alternate long and short foraging trips in pelagic seabird parents. Anim Behav 47:472-476

Williams TD (1991) Foraging ecology and diet of gentoo penguins Pygoscelis papua at South Georgia during winter and an assessment of their winter prey consumption. Ibis 133:3-13

Williams TD (1995) The penguins: Spheniscidae. Oxford University Press, Oxford

Williams TD, Croxall JP (1991) Annual variation in breeding biology of macaroni penguins, Eudyptes chrysolophus, at Bird Island, South Georgia. J Zool 223:189-202

Submitted: June 17, 2005; Accepted: September 12, 2005

Proofs received from author(s): March 13, 2006 